Supporting Information

\title{
Photocatalytic Oxygenation and Deoxygenation Transformations over BCN Nanosheets
}

Meifang Zheng, Tao Yuan, Jiale Shi, Wancang Cai, and Xinchen Wang*

State Key Laboratory of Photocatalysis on Energy and Environment, College of Chemistry, Fuzhou University, Fuzhou 350116, China

Email: xcwang@fzu.edu.cn 


\section{General Methods}

If not indicated otherwise, commercially available reagents and solvents were used without further purification. To be specifically, the solvents are organic compounds. After the reactions, the mixtures were centrifuged and the organic layer were disposed as the organic liquid waste.

\section{Synthesis of BCN materials:}

Synthesis of b-BCN: Typically, $2 \mathrm{~g}$ boric acid, $4 \mathrm{~g}$ urea, and $1.6 \mathrm{~g}$ glucose were grinded fully in an agate mortar. Afterwards, the mixed precursor was put into a horizontal tube furnace. Ammonia was pumped into the tube for about 10 min to expel air before heating up. Then the mixture was heated to $1523 \mathrm{~K}$ for $5 \mathrm{~h}$ at a heating rate of $5 \mathrm{~K} \mathrm{~min}^{-1}$ under a flow of ammonia $\left(0.2 \mathrm{~L} \mathrm{~min}^{-1}\right)$. The obtained products were refluxed in acetonitrile and $0.1 \mathrm{M} \mathrm{HCl}$ at $353 \mathrm{~K}$ for $8 \mathrm{~h}$, then washed with water and dried. The resulting final sample was denoted as b-BCN materials. ${ }^{[2]}$

Synthesis of BCN-X: Typically, $2 \mathrm{~g}$ boric acid, $4 \mathrm{~g}$ urea, $\mathrm{Xg} \mathrm{KCl}(\mathrm{X}=0,2.27,4.54$, or 6.81$)$, and $1.6 \mathrm{~g}$ glucose were grinded fully in an agate mortar. Afterwards, the mixed precursor was put into a horizontal tube furnace. Ammonia was pumped into the tube for about 10 min to expel air before heating up. Then the mixture was heated to $1523 \mathrm{~K}$ for $5 \mathrm{~h}$ at a heating rate of $5 \mathrm{~K} \mathrm{~min}^{-1}$ under a flow of ammonia $\left(0.2 \mathrm{~L} \mathrm{~min}^{-1}\right)$. The obtained products were refluxed in acetonitrile and $0.1 \mathrm{M} \mathrm{HCl}$ at $353 \mathrm{~K}$ for $8 \mathrm{~h}$, then washed with water and dried. The resulting final sample was denoted as m-BCN materials.

\section{Characterization:}

The morphology of the samples was investigated using Hitachi SU8010 field emission scanning electron microscopy (SEM). Transmission electron microscopy (TEM) images were obtained on a JEOL JEM-2010 microscope with an accelerating voltage of $200 \mathrm{kV}$. The selected-area electron diffraction (SAED) were also collected on the TEM machine. Atomic force microscopy (AFM) image was measured on a Nano Scope IV instrument. Nitrogen adsorption-desorption isotherms were collected at $77 \mathrm{~K}$ using a Micromeritics 3Flex surface characterization analyzer and porosity analyzer. Nitrogen adsorption-desorption isotherms were performed at $77 \mathrm{~K}$ using Micromeritics ASAP 3035 equipment. The pore size distribution was estimated with Brrett-Joyner-Halenda (BJH) 
and the specific surface area (SSA) was determined with the Beunauer-Emmett-Teller (BET) method. UV-Visible absorption spectroscopy was analysed using a Shimadzu UV-3600 UV-Vis-NIR spectrophotometer at room temperature. Photoluminescence (PL) was measured on a Hitachi F-7000 FL spectrophotometer. X-ray photoelectron spectroscopy (XPS) was carried out on a Thermo ESCALAB 250 XPS spectrometer. X-ray powder diffraction pattern analysis was conducted on a D8 Advance Bruker X-ray diffractometer with $\mathrm{Cu} K \alpha$ radiation $(\lambda=0.15406 \mathrm{~nm})$ operating at $40 \mathrm{kV}$. Electrochemical measurements were conducted with a BAS Epsilon Electrochemical System in a conventional three electrode cell, using a Pt sheet as the counter electrode and a saturated calomel electrode as the reference electrode, and the active area is confined to ca. $0.25 \mathrm{~cm}^{2}$. The working electrode was prepared on fluorine-tin oxide (FTO) glass. The $5 \mathrm{mg}$ sample was totally dispersed in DMF $(1 \mathrm{~mL})$ by sonication to gain a slurry. Afterward, the resultant slurry was spread onto the FTO glass. Then, the working electrode was dried in the air for $12 \mathrm{~h}$ and further dried at $393 \mathrm{~K}$ for $2 \mathrm{~h}$ to improve adhesion. Then, the Scotch tape was unstuck, and the uncoated part of the electrode was isolated with epoxy resin. The frequency used for the EIS analysis is $100 \mathrm{mHz}-100 \mathrm{KHz}$. Electron paramagnetic resonance (EPR) measurement was carried out with Bruker model A300 spectrometer.

\section{Photoreactor Configuration}

Reactions were irradiated using a simple photoreactor consisting of Eaglerise ELP8X3LS 3W blue LEDs $(\lambda=455 \mathrm{~nm})$, which was connected to HAAKE-FK cyclic water-cooling system. In order to ensure that the reactions are run near room temperature, a simple cooling fan was installed above the reactor to aid in dissipating the heat generated from both nonradioactive decay pathways of the excited state catalysts and the heat generated from the LEDs. An equilibrium temperature of $25^{\circ} \mathrm{C}$ was measured with a standard alcohol thermometer. ${ }^{[1]}$ 


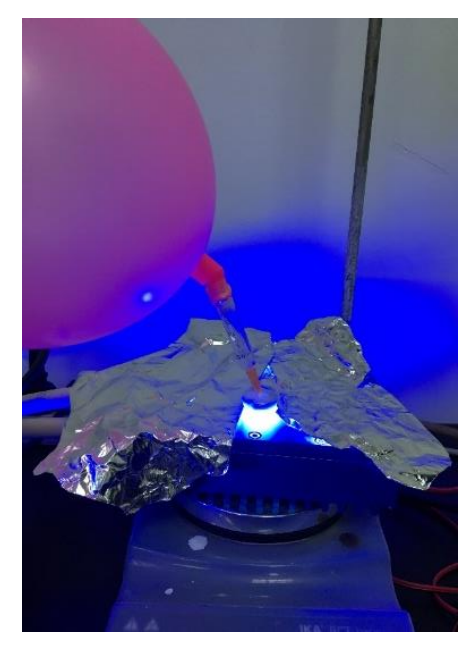

Reactions were irradiated using a simple photoreactor consisting of $15 \mathrm{~W} 420 \mathrm{~nm}$ LEDs with a cooling system with an equilibrium temperature of $25^{\circ} \mathrm{C}$ cooling system. ${ }^{[2]}$

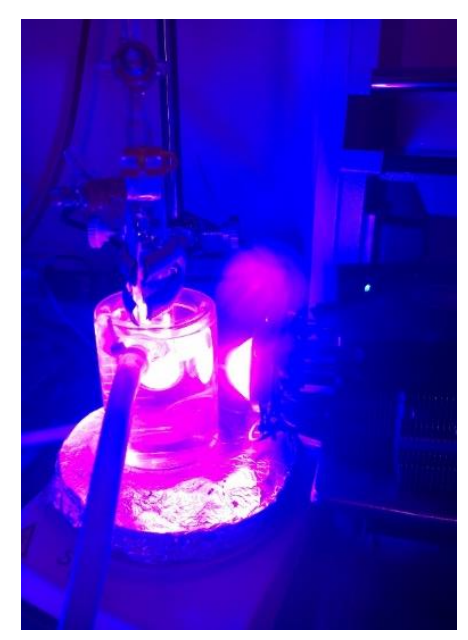

Analytical TLC was performed on silica gel coated glass plates. Column chromatographic purification of products was accomplished using 200-300 mesh silica gel. NMR spectra were measured on a Bruker Avance spectrometer (400 MHz) in the indicated solvents; Coupling constants are reported in $\mathrm{Hz}$ with multiplicities denoted as s (singlet), $\mathrm{d}$ (doublet), $\mathrm{t}$ (triplet), $\mathrm{q}$ (quartet) and $\mathrm{m}$ (multiplet). Gas chromatography-mass spectra (GC-MS) were taken at Thermo Trace 1300 gas chromatograph mass spectrometer and a TR-5MS: column $(0.25 \mathrm{~mm} \times 30 \mathrm{~m}$, Film: $0.25 \mu \mathrm{m})$. Analytical gas chromatography (GC) for the samples were carried out on a SHIMDZU GC-2014ATF/SPL (TDX-01 60/80 mesh, 2.0 mm x 3.2 mm x 2.1 mm-FID, TCD permanent gases, $\mathrm{N}_{2}$ carrier gas). 


\section{Structure and optical characterization of $\boldsymbol{h}-\mathrm{BCN}$}
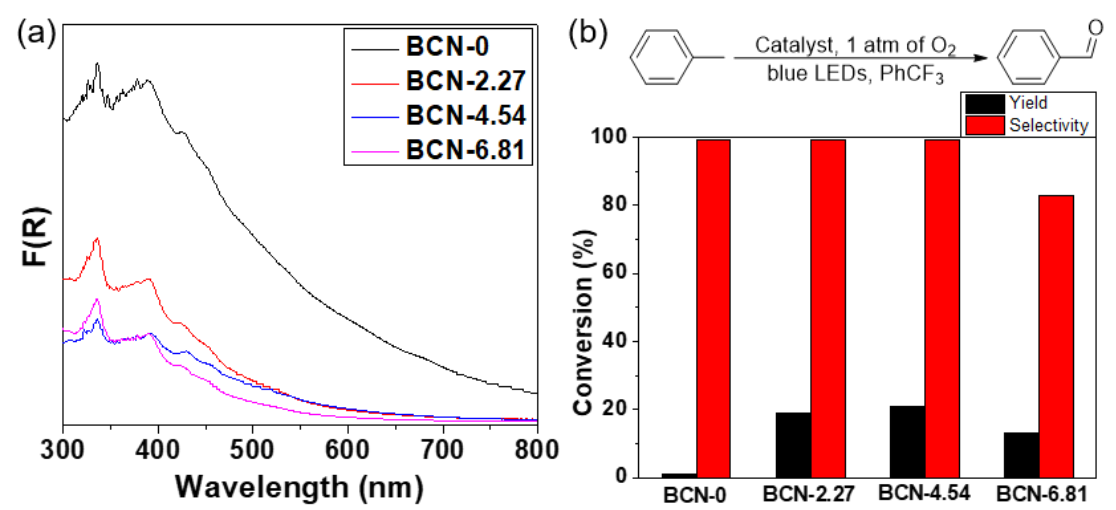

Figure S1. (a) UV-vis DRS of the BCN materials. (b) Reaction Conditions: toluene (1.0 mmol), BCN-X (20 mg), $\mathrm{PhCF}_{3}(2.0 \mathrm{~mL})$, irradiation with $455 \mathrm{~nm}$ LEDs for $24 \mathrm{~h}$ at room temperature, the yield is determined by liquid chromatography (LC) with benzoether as the internal standard. To be specifically, b-BCN represents $\mathrm{BCN}-0$ and m-BCN represents BCN-4.54 in the following text.
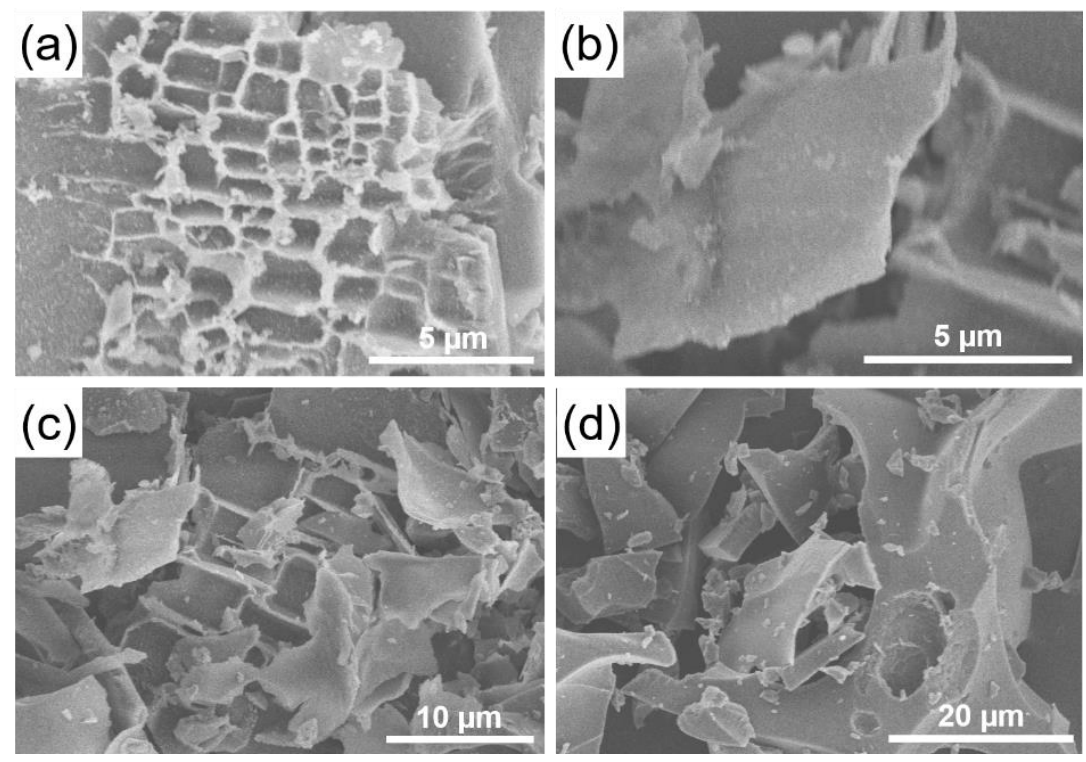

Figure S2. SEM of m-BCN and b-BCN. (a)-(b) SEM image of b-BCN. (c)-(d) SEM image of $\mathrm{m}-\mathrm{BCN}$. 

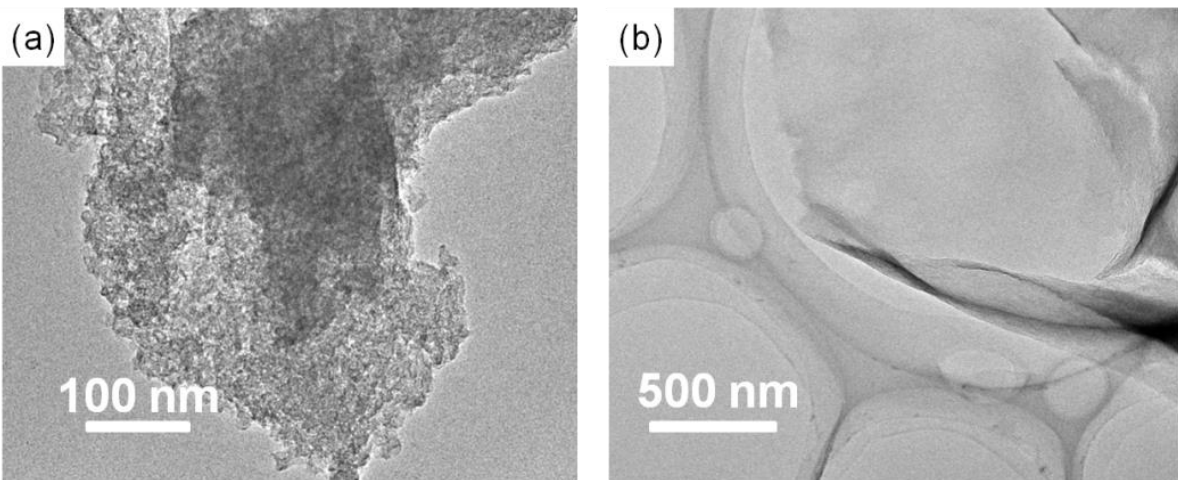

Figure S3. TEM of m-BCN and b-BCN. (a) TEM image of b-BCN (scale bar: $100 \mathrm{~nm}$ ). (b) TEM image of m-BCN (scale bar: $500 \mathrm{~nm}$ ).
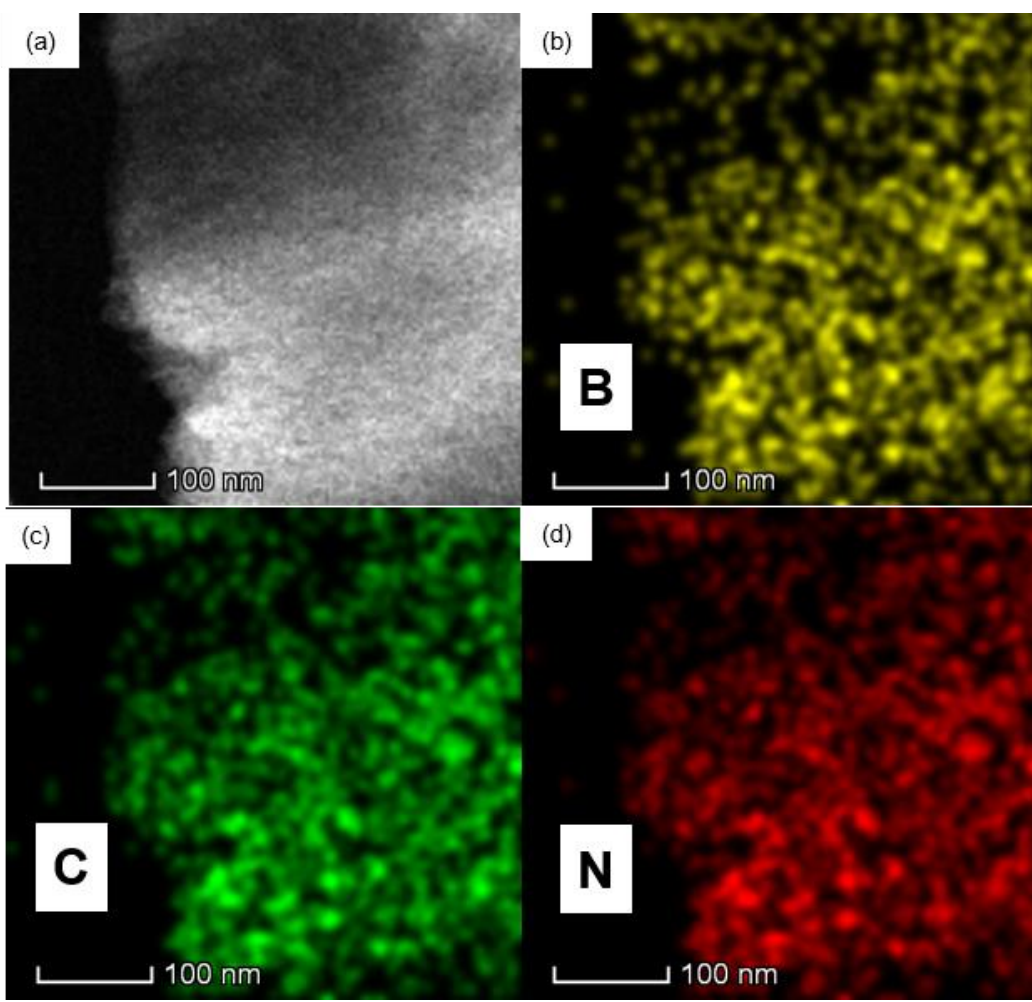

Figure S4. The EDX mapping results of m-BCN. Elemental mapping images of (b) B, (c) C, and (d) N, respectively. Scale bar, $100 \mathrm{~nm}$. 

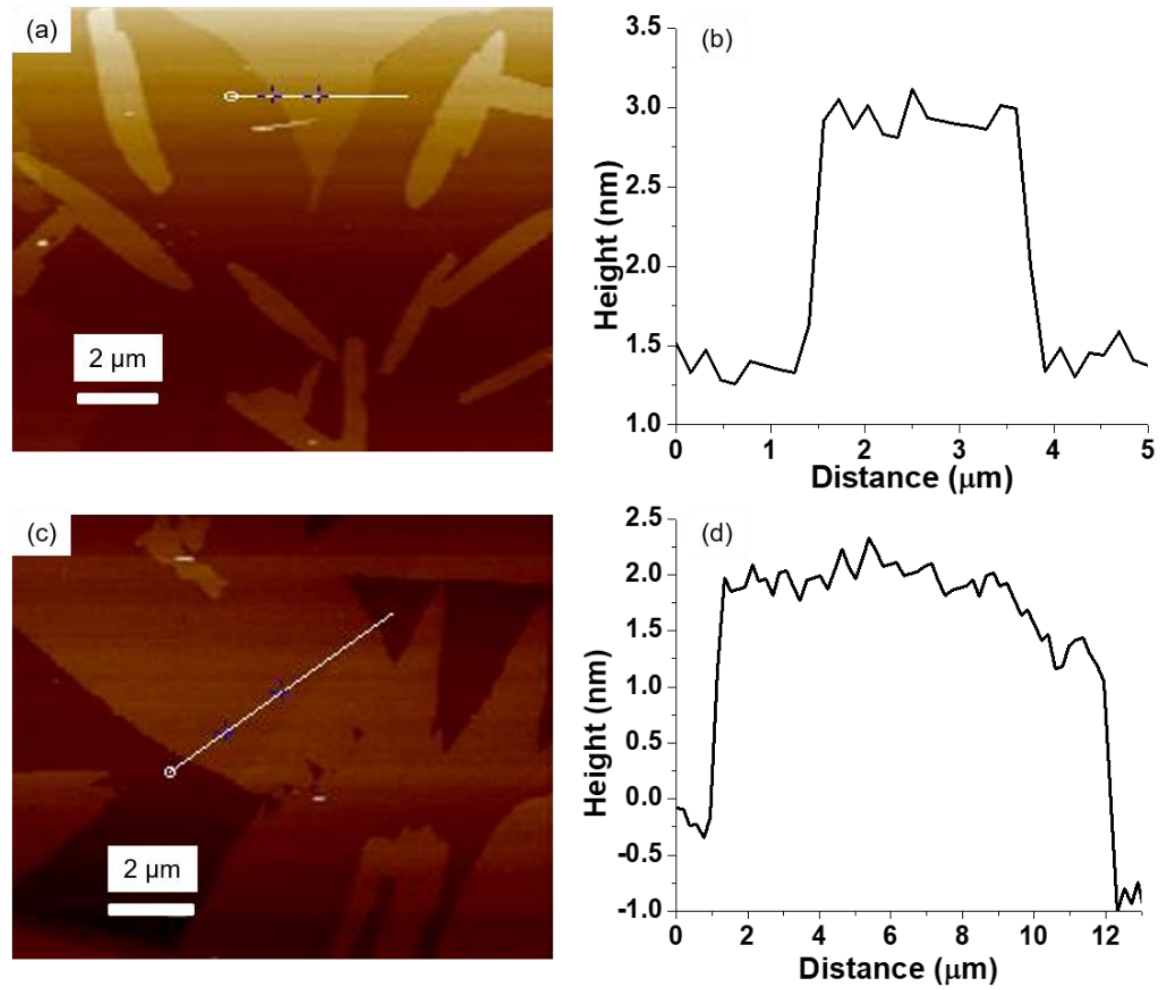

Figure S5. AFM of m-BCN. (b) and (d) are the height images corresponding to (a) and (c), respectively.

Table S1. The content of the BCN materials.

\begin{tabular}{ccccc}
\hline Sample & Boron(wt.\%) & Carbon(wt.\%) & Nitrogen(wt.\%) & Oxygen(wt.\%) \\
\hline b-BCN ${ }^{[1]}$ & 40.2 & 13.9 & 35.6 & 10.3 \\
m-BCN & 40.7 & 13.4 & 36.7 & 9.2 \\
\hline
\end{tabular}




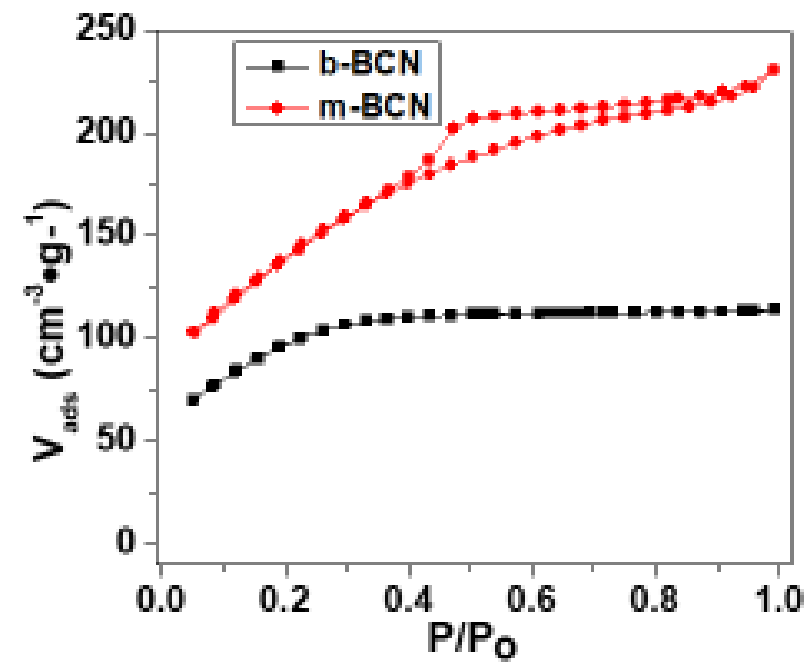

Figure S6. $\mathrm{N}_{2}$-sorption isotherms collected at $77 \mathrm{~K}$.

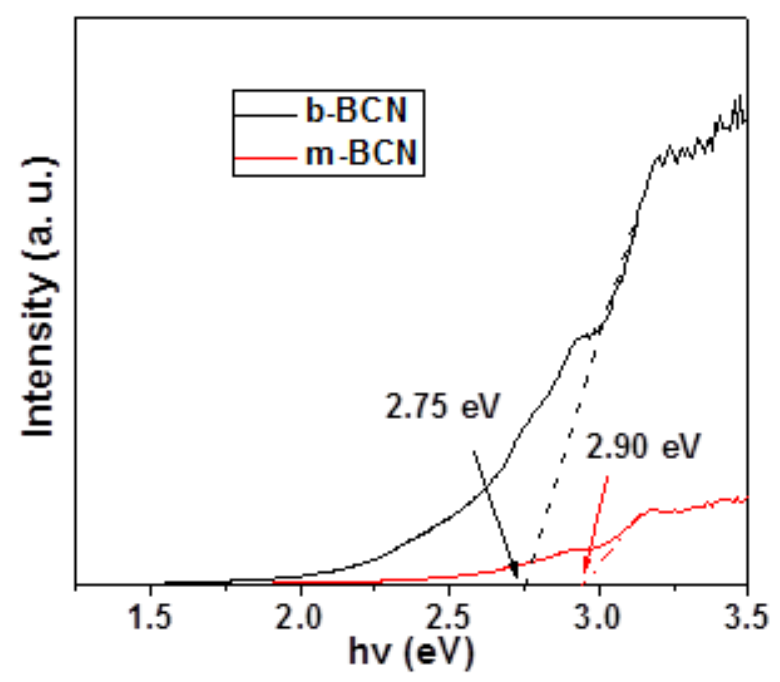

Figure S7. The bandgap of $\mathrm{m}-\mathrm{BCN}$ and b-BCN from UV-vis DRS spectrum determined by Tauc plot. 


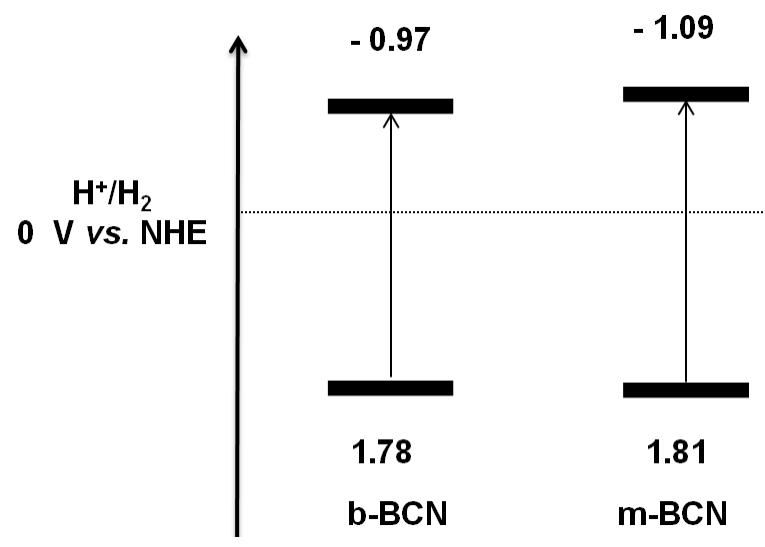

Figure S8. Schematic illustration of the band structures of b-BCN and m-BCN.

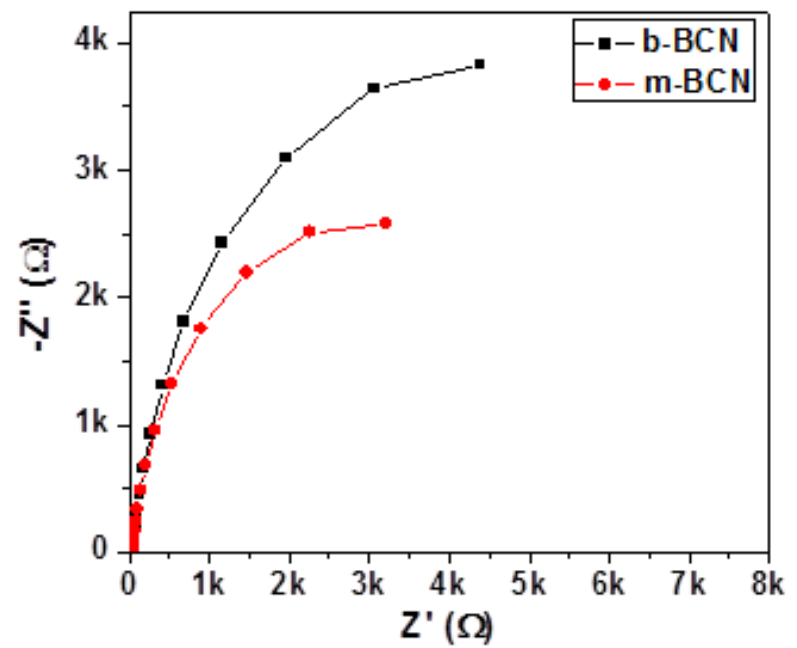

Figure S9. EIS Nyquist of $\mathrm{m}-\mathrm{BCN}$ and b-BCN samples. 
Table S2. Optimization of the selective oxidation of toluene.

\begin{tabular}{|c|c|c|c|c|c|}
\hline Entry & Catalyst & Solvent & $h v$ & Yield $^{[\mathrm{a}]}$ & Selectivity \\
\hline 1 & $\mathrm{~m}-\mathrm{BCN}$ & $\mathrm{CH}_{3} \mathrm{CN}$ & Blue LEDs & $6 \%$ & $99 \%$ \\
\hline 2 & $\mathrm{~m}-\mathrm{BCN}$ & 1,4-dioxane & Blue LEDs & trace & - \\
\hline 3 & $\mathrm{~m}-\mathrm{BCN}$ & DMSO & Blue LEDs & $12 \%$ & $50 \%$ \\
\hline 4 & $\mathrm{~m}-\mathrm{BCN}$ & $\mathrm{PhCF}_{3}$ & Blue LEDs & $21 \%$ & $99 \%$ \\
\hline 5 & $\mathrm{~m}-\mathrm{BCN}$ & DMF & Blue LEDs & $1 \%$ & $99 \%$ \\
\hline 6 & $\mathrm{~m}-\mathrm{BCN}$ & 1,2-DCE & Blue LEDs & $8 \%$ & $99 \%$ \\
\hline $7^{[b]}$ & $\mathrm{m}-\mathrm{BCN}$ & $\mathrm{PhCF}_{3}$ & Blue LEDs & n.d. & - \\
\hline $8^{[\mathrm{c}]}$ & $\mathrm{m}-\mathrm{BCN}$ & $\mathrm{PhCF}_{3}$ & - & trace & - \\
\hline $9^{[\mathrm{d}]}$ & - & $\mathrm{PhCF}_{3}$ & Blue LEDs & n.d. & - \\
\hline
\end{tabular}

[a] Reaction Conditions: substrate $(1.0 \mathrm{mmol}), h$-BCN $(20 \mathrm{mg})$, Solvent $(2.0 \mathrm{~mL})$, and irradiation with $455 \mathrm{~nm}$ LEDs for $24 \mathrm{~h}$ at room temperature, yields are determined by liquid chromatography (LC) with benzoether as the internal standard. [b] The reaction is operated in $\mathrm{N}_{2}$ atmosphere. [c] The reaction is operated without light. [d] The reaction is operated without the $\mathrm{m}-\mathrm{BCN}$.

To be specifically, the solvents are organic compounds. After the reaction, the mixtures were centrifuged and the organic layer are disposed as the organic liquid waste.

For the oxidation of hydrocarbons, the formula of the conversion rate, selectivity, and yield were defined as follows:

$$
\begin{aligned}
& \text { Conversion }(\%)=\left[\left(C_{0}-C_{\text {remain }}\right) / C_{0}\right] * 100 \% \\
& \text { Yield }(\%)=C_{\text {aldehyde }} / C_{o} * 100 \% \\
& \text { Selectivity }(\%)=\left[C_{\text {aldehyde }} /\left(C_{0}-C_{\text {remain }}\right)\right] * 100 \%
\end{aligned}
$$




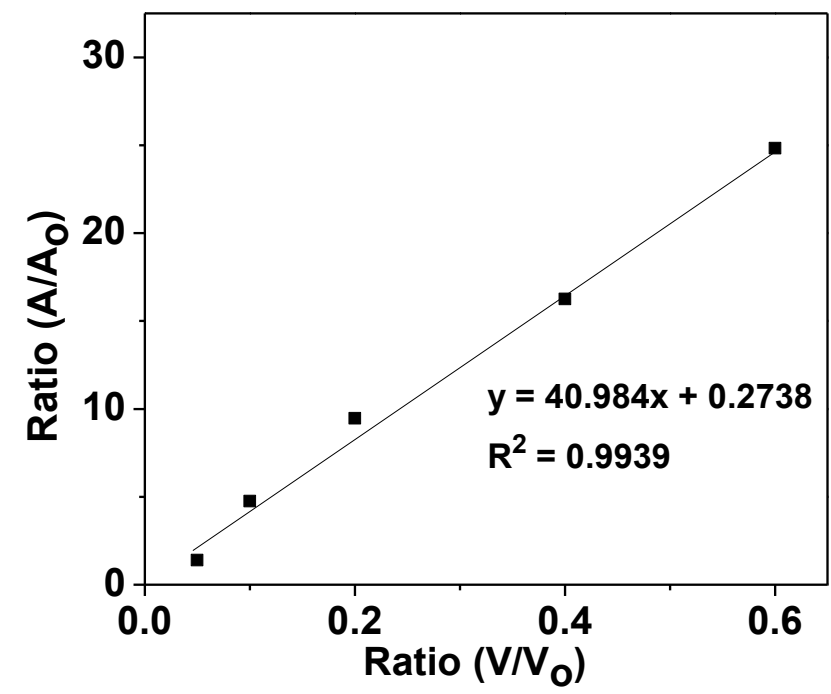

Figure S10. Standard curve of aldehyde with benzoether as internal standard.

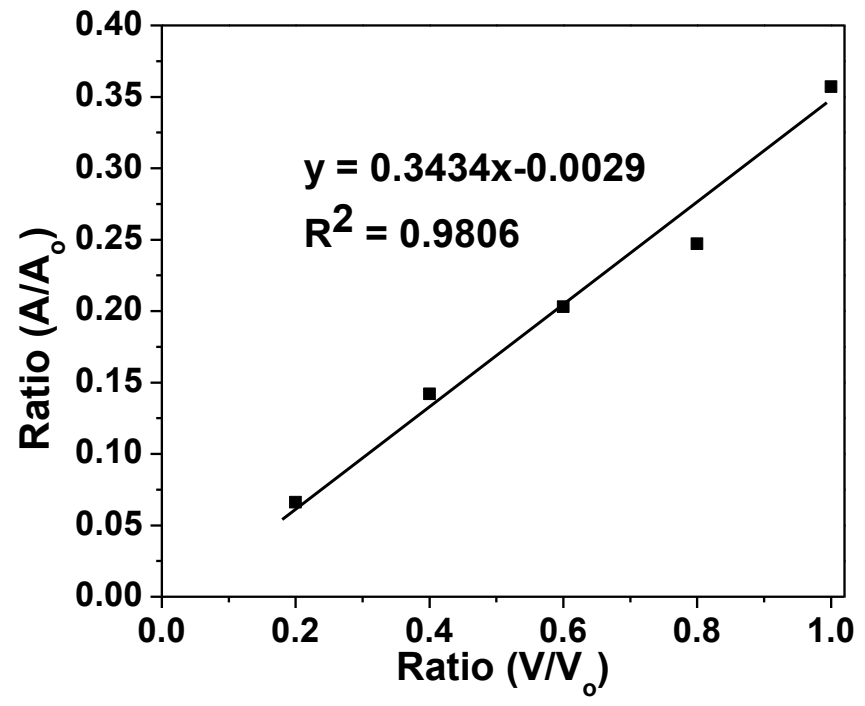

Figure S11. Standard curve of toluene with benzoether as internal standard. 


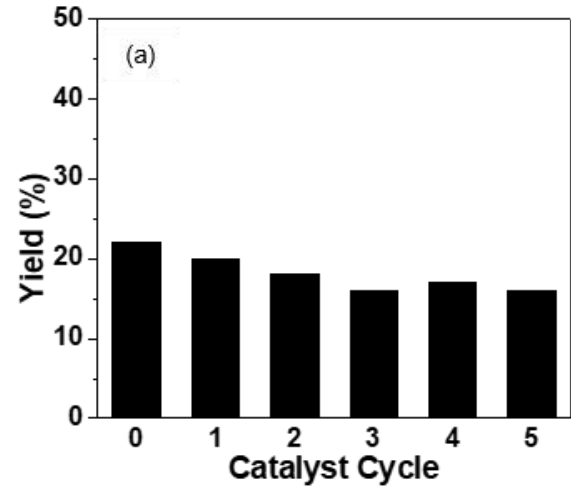

(c)

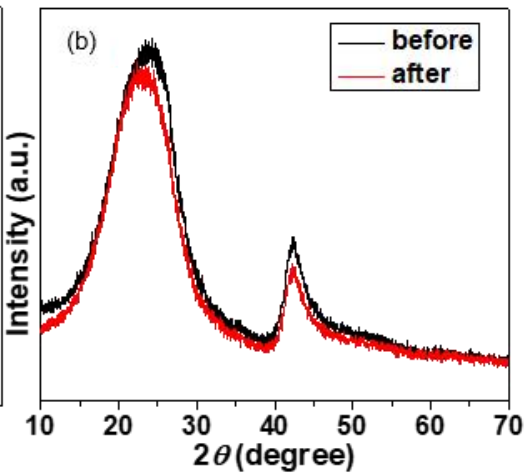

(d)

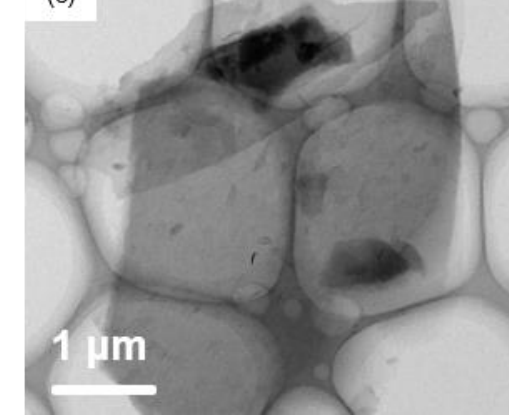

\section{$20 \mathrm{~nm}$}

Figure S12. (a) Catalyst cycle test. (b) XRD of $\mathrm{m}-\mathrm{BCN}$ before and after the reaction. (c)-(d) TEM images of $\mathrm{m}-\mathrm{BCN}$ after the reaction.

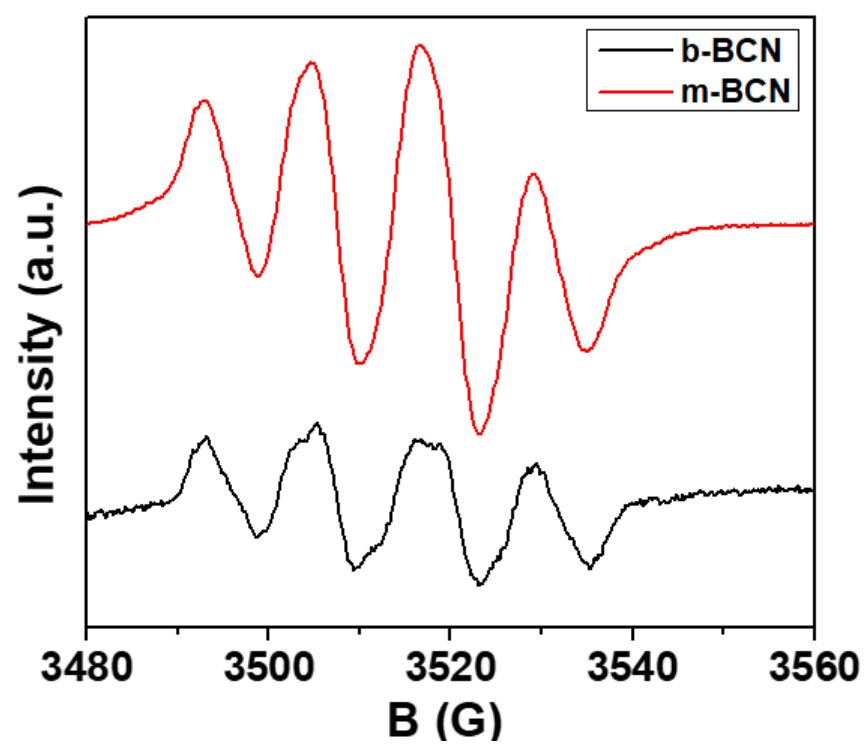

Figure S13. DMPO spin-trapping EPR spectra for b-BCN and $\mathrm{m}-\mathrm{BCN}$ for superoxide radical $\left(\mathrm{O}^{-}{ }^{-}\right)$in $\mathrm{PhCF}_{3}$, the spectra were taken under the irradiation for $10 \mathrm{~min}$. 
Table S3. The reported yields of different heterogeneous catalyst for the oxidation of toluene.

\begin{tabular}{|c|c|c|c|c|c|c|c|}
\hline & Catalyst & Oxidant & $\begin{array}{c}\text { Temperature } \\
\left({ }^{\circ} \mathrm{C}\right)\end{array}$ & $\begin{array}{l}\text { Time } \\
\text { (h) }\end{array}$ & $\begin{array}{c}\text { Conversion } \\
(\%)\end{array}$ & $\begin{array}{c}\text { Yield } \\
(\%)\end{array}$ & $\begin{array}{c}\text { Selectivity } \\
(\%)\end{array}$ \\
\hline $1^{3}$ & $1 \% \mathrm{Au}-\mathrm{Pd} \mathrm{TiO}_{2}$ & TBHP & 80 & $4 \mathrm{~h}$ & 5.3 & 17 & 32 \\
\hline $2^{4}$ & $\begin{array}{c}\mathrm{Au} 144 @ \\
\mathrm{mCeO}_{2}\end{array}$ & $\begin{array}{c}10 \text { bar of } \\
\mathrm{O}_{2}\end{array}$ & 120 & 24 & 6.6 & 4.4 & 67 \\
\hline $3^{5}$ & Mn-ZSM-5 & $\begin{array}{c}1 \mathrm{~atm} \text { of } \\
\mathrm{O}_{2}\end{array}$ & 400 & 2 & 65 & 65 & 100 \\
\hline $4^{6}$ & Graphene/g- $\mathrm{C}_{3} \mathrm{~N}_{4}$ & $\begin{array}{c}10 \text { bar of } \\
\mathrm{O}_{2}\end{array}$ & 150 & 4 & 12 & 12 & $99 \%$ \\
\hline 5 & $\mathrm{~m}-\mathrm{BCN}$ & $\begin{array}{l}5 \text { equiv } \\
\text { of } \mathrm{H}_{2} \mathrm{O}_{2}\end{array}$ & 150 & 2 & 12.4 & 12 & $99 \%$ \\
\hline
\end{tabular}

Table S4. b-BCN nanosheets for photocatalytic oxidation and reduction.

\begin{tabular}{|c|c|c|c|c|}
\hline Entry & Substrate & Product & Yield $^{a}$ & Selectivity \\
\hline $1^{b}$ & $\mathrm{Ph}$ & & $48 \%$ & $100 \%$ \\
\hline $2^{c}$ & & & $49 \%$ & $50 \%$ \\
\hline $3^{d}$ & $\mathrm{Ph}-\mathrm{NO}_{2}$ & $\mathrm{Ph}-\mathrm{NH}_{2}$ & $33 \%$ & $65 \%$ \\
\hline $4^{e}$ & $\mathrm{Ph}-\mathrm{SO}_{2} \mathrm{NH}_{2}$ & & trace & - \\
\hline $5^{e}$ & $\mathrm{Ph}-\mathrm{SO}_{2} \mathrm{Na}$ & & trace & - \\
\hline
\end{tabular}

[a] Isolated yield. [b] Substrate (1.0 mmol), b-BCN (20 mg), $\mathrm{CH}_{3} \mathrm{CN}(2.0 \mathrm{~mL})$, irradiation with $455 \mathrm{~nm}$ LEDs for $12 \mathrm{~h}$ at room temperature. [c] Substrate $(1.0 \mathrm{mmol}), \mathrm{b}-\mathrm{BCN}(20 \mathrm{mg}), \mathrm{CH}_{3} \mathrm{CN}(2.0 \mathrm{~mL})$, irradiation with $455 \mathrm{~nm}$ LEDs for $4 \mathrm{~h}$ at room temperature. [d] Nitrobenzene (1.0 mmol), b-BCN (20 mg), $\operatorname{PrOH}(3.0 \mathrm{~mL})$, HBpin ( $0.1 \mathrm{mmol}, 15 \mu \mathrm{L}), \mathrm{pH}=12$, the reaction mixture was operated with $455 \mathrm{~nm}$ LEDs irradiation for $24 \mathrm{~h}$ at room temperature. [e] Substrate $(0.30 \mathrm{mmol}), \mathrm{b}-\mathrm{BCN}(20 \mathrm{mg}), i \mathrm{PrOH}(2.0 \mathrm{~mL})$, and HBpin $(0.6 \mathrm{mmol}, 88$ $\mu \mathrm{L}, 2.0$ equiv), $\mathrm{pH}=12$, the reaction mixture was irradiation with $420 \mathrm{~nm}$ LEDs for $24 \mathrm{~h}$ at room temperature. 


\section{Procedures of the semiconductor photoredox reactions}

\section{Procedure for Oxygenation of $\mathrm{sp}^{3} \mathrm{C}-\mathrm{H}$ bonds}

In a dried $10 \mathrm{~mL}$ quartz tube, $1.0 \mathrm{mmol}$ of hydrocarbons, and $20 \mathrm{mg}$ of b-BCN were taken in $2 \mathrm{~mL}$ of $\mathrm{PhCF}_{3}$ under air atmosphere. The resulting reaction mixture was irradiated by blue LEDs for 24 h, cooled with $25^{\circ} \mathrm{C}$ condensate circulating water. After completion, reaction mixture was filtered to separate the solid catalyst. The filter was detected by LC.

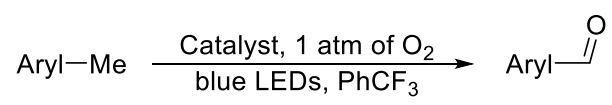

\section{Procedure for Oxygenation of $\mathrm{sp}^{3} \mathrm{C}-\mathrm{H}$ bonds}

In a dried $10 \mathrm{~mL}$ quartz tube, $1.0 \mathrm{mmol}$ of diphenylmethane, and $20 \mathrm{mg}$ of b-BCN were taken in 2 $\mathrm{mL}$ of $\mathrm{CH}_{3} \mathrm{CN}$ under air atmosphere. The resulting reaction mixture was irradiated by blue LEDs for $6 \mathrm{~h}$, cooled with $25{ }^{\circ} \mathrm{C}$ condensate circulating water. After completion, reaction mixture was filtered to separate the solid catalyst. The solid catalyst was washed with deionized water and ethyl acetate properly and dry it in vacuum for next cycle practice. Then the filtrate was extracted with ethyl acetate $(10.0 \mathrm{~mL} \times 3)$. Organic part was washed with water and dried over anhydrous $\mathrm{Na}_{2} \mathrm{SO}_{4}$, followed by complete removal of solvent by reduced pressure distillation. The resulting crude mass was purified by silica gel column chromatography in petroleum ether/ethyl acetate $(20: 1, v / v)$ to afford pure products.<smiles>O=C(c1ccccc1)c1ccccc1</smiles>

\section{Benzophenone $e^{[7]}$}

White solid, $129.2 \mathrm{mg}$, yield of $71 \%$. ${ }^{1} \mathrm{H}$ NMR $\left(400 \mathrm{MHz}, \mathrm{CDCl}_{3}\right) \delta=7.81(\mathrm{~d}, J=7.8,4 \mathrm{H}), 7.59$ (t, $J=7.2,2 \mathrm{H}), 7.49$ (t, $J=7.5,4 \mathrm{H}) .{ }^{13} \mathrm{C}$ NMR $\left(101 \mathrm{MHz}, \mathrm{CDCl}_{3}\right) \delta=196.79,137.59,132.43,130.08$, 128.29 .

\section{Procedure for the oxidation of methyl(phenyl)sulfane}

In a dried $10 \mathrm{~mL}$ quartz tube, $1.0 \mathrm{mmol}$ of methyl(phenyl)sulfane, and $20 \mathrm{mg}$ of b-BCN were taken in $2 \mathrm{~mL}$ of $\mathrm{CH}_{3} \mathrm{CN}$ under air atmosphere. The resulting reaction mixture was degassed and stirred under $\mathrm{O}_{2}$ atmosphere for $24 \mathrm{~h}$ under blue LEDs, cooled with $25{ }^{\circ} \mathrm{C}$ condensate circulating water. After completion, reaction mixture was filtered to separate the solid catalyst. The solid catalyst was washed with water and ethyl acetate properly and dry it in vacuum for next cycle practice. Then the filtrate was extracted with ethyl acetate $(10.0 \mathrm{~mL} \times 3)$. Organic part was washed with water and dried over anhydrous $\mathrm{Na}_{2} \mathrm{SO}_{4}$ followed by complete removal of solvent. The resulting crude mass was purified by silica gel column chromatography in petroleum ether/ethyl acetate $(9: 1, \mathrm{v} / \mathrm{v})$ to afford pure product.<smiles>COc1ccc(S(C)(=O)=O)cc1</smiles>

1-Methoxy-4-(methylsulfonyl)benzene ${ }^{[8]}$ 
White solid, $182.3 \mathrm{mg}$, yield of 98\%. ${ }^{1} \mathrm{H}$ NMR (400 MHz, $\left.\mathrm{CDCl}_{3}\right) \delta=7.86(\mathrm{~d}, J=7.8,2 \mathrm{H}), 7.01(\mathrm{~d}$, $J=7.8,2 \mathrm{H}), 3.88(\mathrm{~s}, 3 \mathrm{H}), 3.02(\mathrm{~s}, 3 \mathrm{H}) .{ }^{13} \mathrm{C} \mathrm{NMR}\left(101 \mathrm{MHz}, \mathrm{CDCl}_{3}\right) \delta=163.71,132.33,129.55,114.51$, $55.71,44.86$.

\section{Procedure for the reduction of nitrobenzene}

In a flame-dried $10 \mathrm{~mL}$ quartz tube, $1.0 \mathrm{mmol}$ of nitrobenzene, $10 \mathrm{mg}$ of $\mathrm{NaOH}$ and $20 \mathrm{mg}$ b-BCN were taken in $3 \mathrm{~mL}$ of 2-propanol. The resulting reaction mixture was degassed and inset with nitrogen, and $0.1 \mathrm{mmol}$ of HBpin $(15 \mu \mathrm{L})$ was added by syringe. Then the mixture was stirred under blue LEDs for $24 \mathrm{~h}$, cooled with $25{ }^{\circ} \mathrm{C}$ condensate circulating water. After completion, reaction mixture was filtered to separate the solid catalyst. The solid catalyst was washed with alcohol properly and dry it in vacuum for next cycle practice. Then the filtrate was moved to the rotate vapor for complete removal of solvent. The resulting crude mass was purified by silica gel column chromatography in petroleum ether/ethyl acetate $(5: 1, \mathrm{v} / \mathrm{v})$ to afford pure aniline oil.<smiles>Nc1ccccc1</smiles>

\section{Aniline $^{[9]}$}

Light yellow oil, $38.1 \mathrm{mg}, 41 \%$ yield. ${ }^{1} \mathrm{H}$ NMR $\left(400 \mathrm{MHz}, \mathrm{CDCl}_{3}\right) \delta=8.20(\mathrm{~d}, J=7.8,2 \mathrm{H}), 7.69$ (t, $J=7.3,1 \mathrm{H}), 7.53(\mathrm{t}, J=7.5,2 \mathrm{H}) .{ }^{13} \mathrm{C} \mathrm{NMR}\left(101 \mathrm{MHz}, \mathrm{CDCl}_{3}\right) \delta=148.18,134.62,129.32,123.45$.

\section{Procedure for the reduction of sulfoxide derivatives}

In a flame-dried $10 \mathrm{~mL}$ quartz tube, $0.3 \mathrm{mmol}$ of sulfoxide derivatives, $10 \mathrm{mg}$ of $\mathrm{NaOH}$ and $20 \mathrm{mg}$ of b-BCN were taken in $2 \mathrm{~mL}$ of 2-propanol. The mixture was degassed and inset with nitrogen, and $0.6 \mathrm{mmol}$ of HBpin $(88 \mu \mathrm{L})$ by syringe. Then the mixture was stirred under $420 \mathrm{~nm}$ LEDs for $24 \mathrm{~h}$, cooled with $25{ }^{\circ} \mathrm{C}$ condensate circulating water. After completion, reaction mixture was filtered to separate the solid catalyst. The solid catalyst was washed with water and ethyl acetate properly and dry it in vacuum for next cycle practice. Then the filtrate was extracted with ethyl acetate $(10.0 \mathrm{~mL} \times 3)$. Organic part was washed with water and dried over anhydrous $\mathrm{Na}_{2} \mathrm{SO}_{4}$ followed by complete removal of solvent. The resulting crude mass was purified by silica gel column chromatography in petroleum ether/ethyl acetate $(6: 1, \mathrm{v} / \mathrm{v})$ to afford the final products.

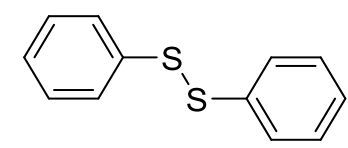

\section{1,2-Diphenyldisulfane ${ }^{[10]}$}

White solid, $25.5 \mathrm{mg}, 39 \%$ yield. ${ }^{1} \mathrm{H}$ NMR (400 MHz, $\left.\mathrm{CDCl}_{3}\right) \delta=7.55(\mathrm{~d}, J=7.7,4 \mathrm{H}), 7.35$ (t, J=7.2, $4 \mathrm{H}), 7.28(\mathrm{~d}, J=6.8,2 \mathrm{H}) .{ }^{13} \mathrm{C}$ NMR $\left(101 \mathrm{MHz}, \mathrm{CDCl}_{3}\right) \delta=137.08,129.10,127.56,127.19$.

\section{Reference}

[1] Ghosh, I.; Ghosh, T.; Bardagi, J. I.; König, B. Reduction of Aryl Halides by Consecutive Visible Light-Induced Electron Transfer Processes. Science 2014, 346, 725-728.

[2] Zheng, M. F.; Shi, J. L.; Yuan, T.; Wang, X. C. Metal-Free Dehydrogenation of $\mathrm{N}-$ Heterocycles by Ternary $h$-BCN Nanosheets with Visible Light. Angew. Chem. Int. Ed. 2018, 57, 5487-5491. 
[3] bin Saiman, M. I.; Brett, G. L.; Tiruvalam, R.; Forde, M. M.; Sharples, K.; Thetford, A.; Jenkins, R. L.; Dimitratos, N.; Lopez-Sanchez, J. A.; Murphy, D. M.; Bethell, D.; Willock, D. J.; Taylor, S. H.; Knight, D. W.; Kiely, C. J.; Hutchings, G. J. Involvement of Surface-Bound Radicals in the Oxidation of Toluene Using Supported Au-Pd Nanoparticles. Angew. Chem. Int. Ed. 2012, 51, 5981-5985.

[4] Liu, Y. L.; Zhang, P. F.; Liu, J. M.; Wang, T.; Huo, Q. S.; Yang, L.; Sun, L.; Qiao, Z. A.; Dai, S. Gold Cluster- $\mathrm{CeO}_{2}$ Nanostructured Hybrid Architectures as Catalysts for Selective Oxidation of Inert Hydrocarbons. Chem. Mater. 2018, 30, 8579-8586.

[5] Li, X. H.; Chen, J. S.; Wang, X. C.; Sun, J. H.; Antonietti, M. Metal-Free Activation of Dioxygen by Graphene/g- $\mathrm{C}_{3} \mathrm{~N}_{4}$ Nanocomposites: Functional Dyads for Selective Oxidation of Saturated Hydrocarbons. J. Am. Chem. Soc. 2011, 133, 8074-8077.

[6] Wang, Y.; Li, H. R.; Yao, J.; Wang, X. C.; Antonietti, M. Photocatalytic Oxidation of Water by Polymeric Carbon Nitride Nanohybrids Made of Sustainable Elements. Chem. Sci. 2011, 2, 446-450.

[7] Jeon, K. O.; Jun, J. H.; Yu, J. S.; Lee, C. K. Infrared and nuclear magnetic resonance properties of benzoyl derivatives of five-membered monoheterocycles and determination of aromaticity indices. J. Heterocyclic Chem. 2003, 40, 763-771.

[8] Yang, H. J.; Li, Y.; Jiang, M.; Wang, J. M.; Fu, H. General Copper-Catalyzed Transformations of Functional Groups from Arylboronic Acids in Water. Chem.-Euro. J 2011, 17, 5652-5660.

[9] Batchelor, R.; Birchall, T. ${ }^{1} \mathrm{H},{ }^{13} \mathrm{C}$, and ${ }^{31} \mathrm{P}$ NMR Study of Primary and Secondary Phenylamines, -Phosphines, and -Arsines and Their Anions. J. Am. Chem. Soc. 1982, 104, 674-679.

[10] Spectral data were obtained from Wiley Subscription Services, Inc. (US) 
NMR spectra

${ }^{1} \mathrm{H}$ spectra of benzophenone

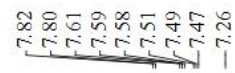
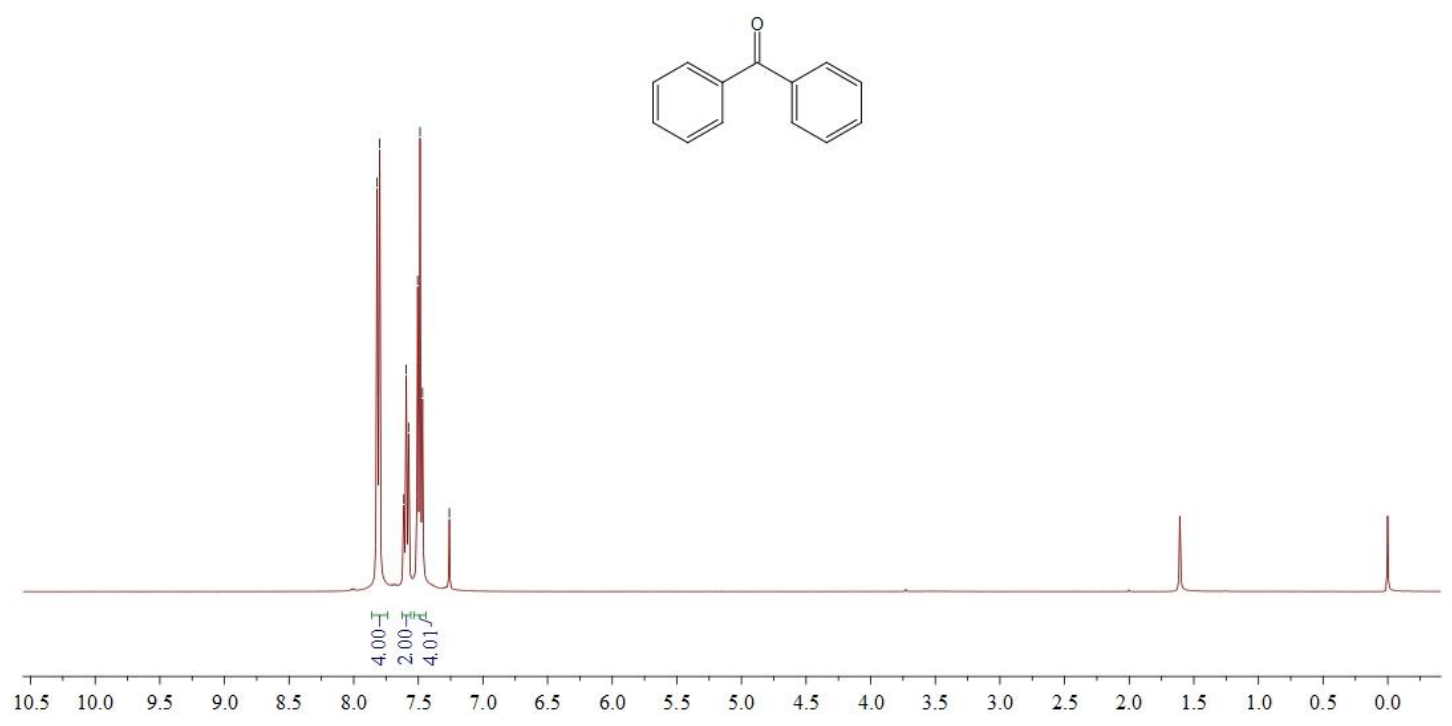

${ }^{13} \mathrm{C}$ spectra of benzophenone

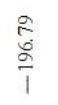

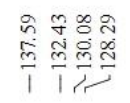

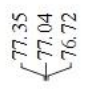

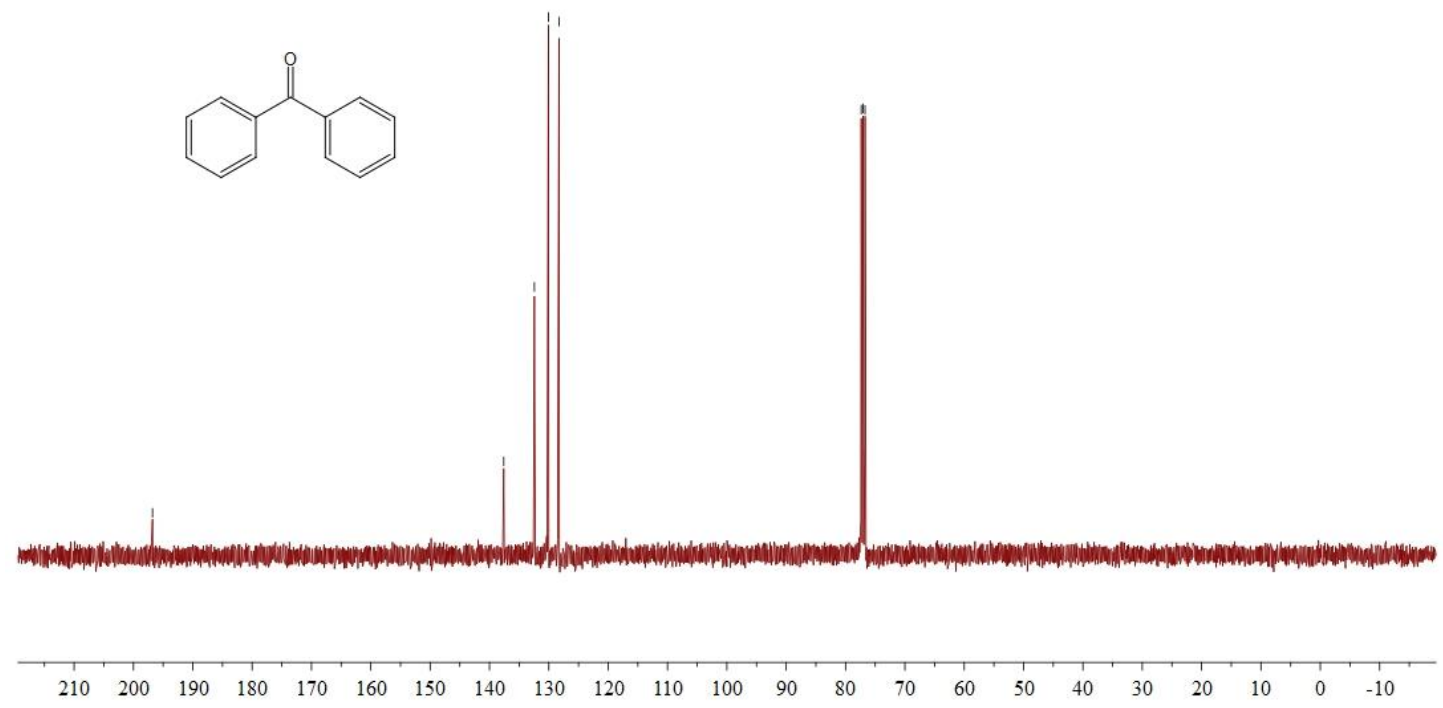


${ }^{1} \mathrm{H}$ spectra of 1-methoxy-4-(methylsulfonyl)benzene
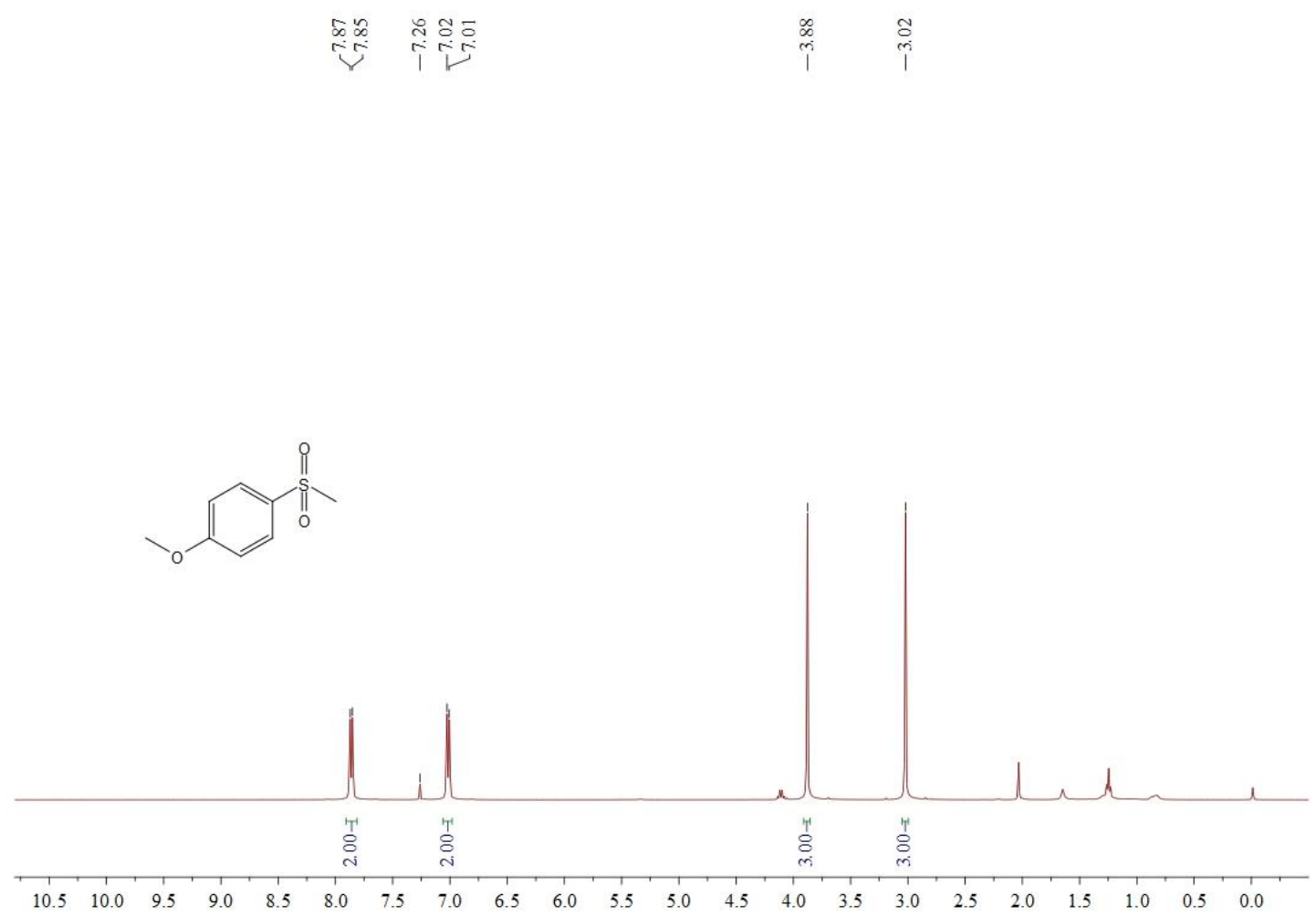

${ }^{13} \mathrm{C}$ spectra of 1-methoxy-4-(methylsulfonyl)benzene

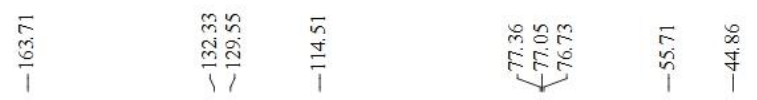<smiles>CCOC(=O)c1ccc(OC)cc1</smiles>

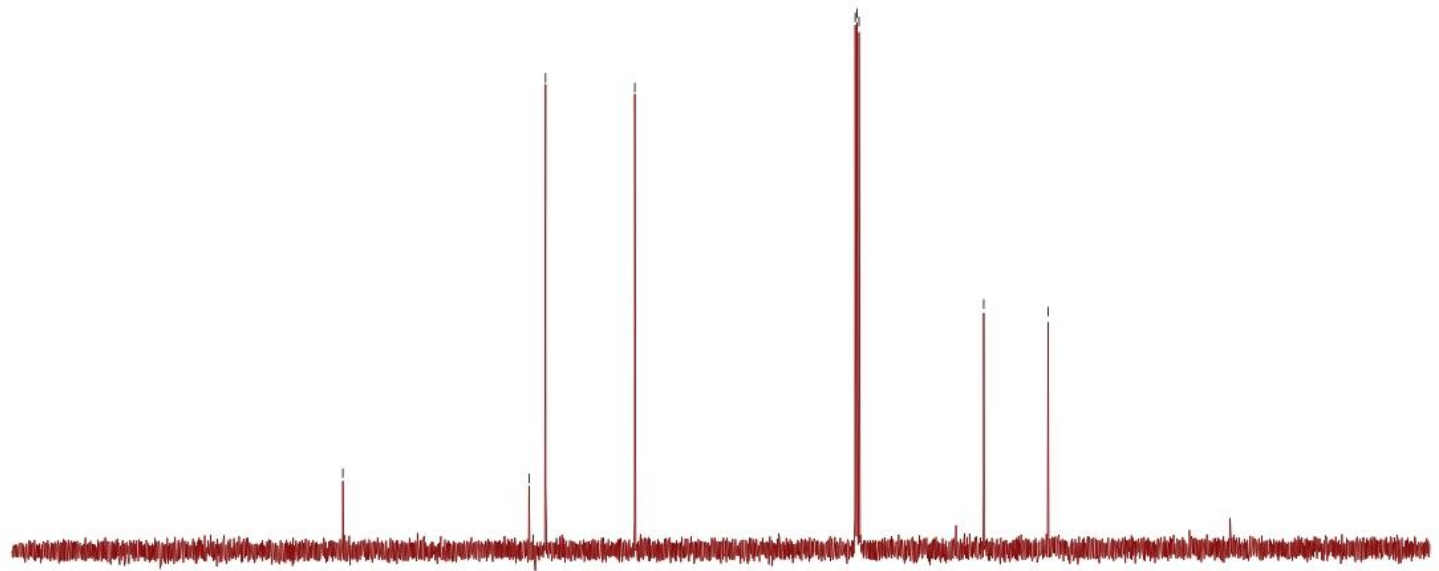

$\begin{array}{llllllllllllllllllllllll}210 & 200 & 190 & 180 & 170 & 160 & 150 & 140 & 130 & 120 & 110 & 100 & 90 & 80 & 70 & 60 & 50 & 40 & 30 & 20 & 10 & 0 & -10\end{array}$ 


\section{${ }^{1} \mathrm{H}$ spectra of aniline}

궁요

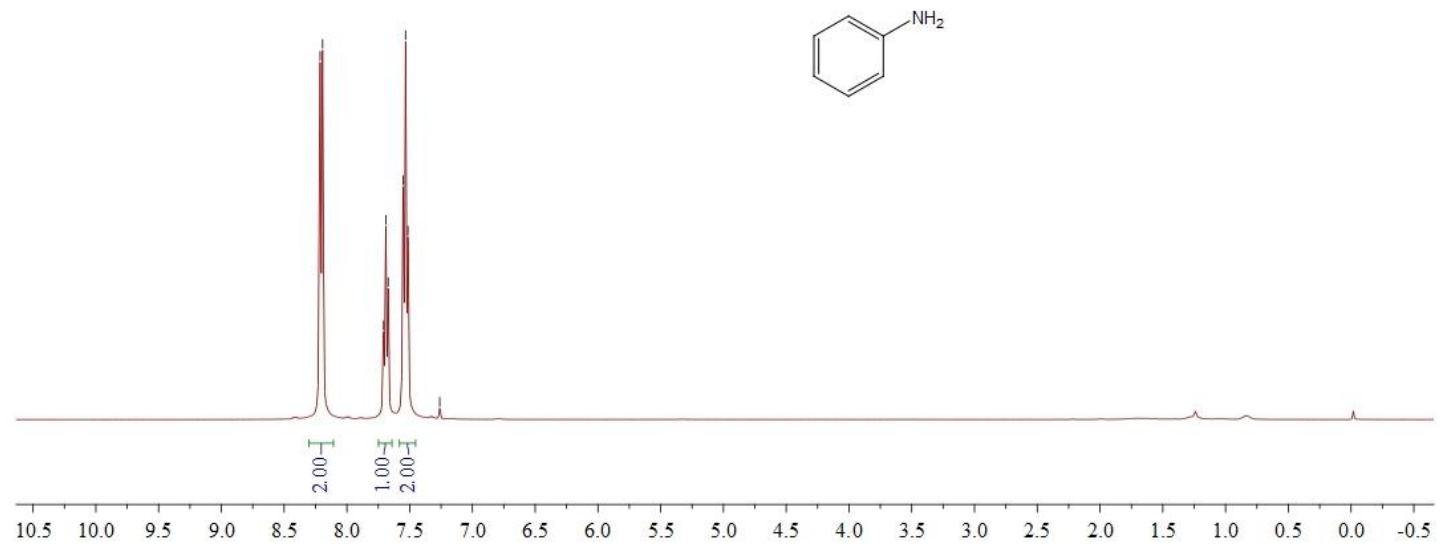

${ }^{13} \mathrm{C}$ spectra of aniline

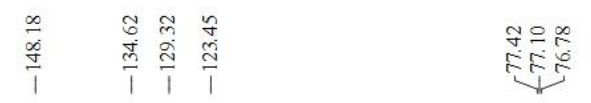

$\mathrm{NH}^{\mathrm{NH}_{2}}$

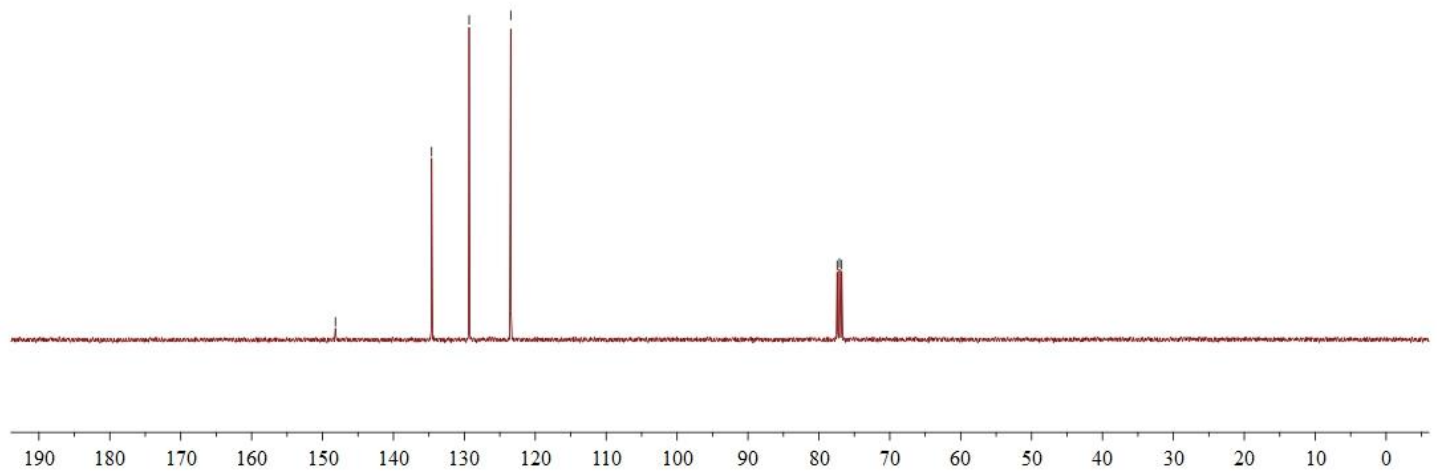


${ }^{1} \mathrm{H}$ spectra of 1,2-diphenyldisulfane

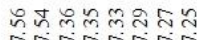

तiviritis

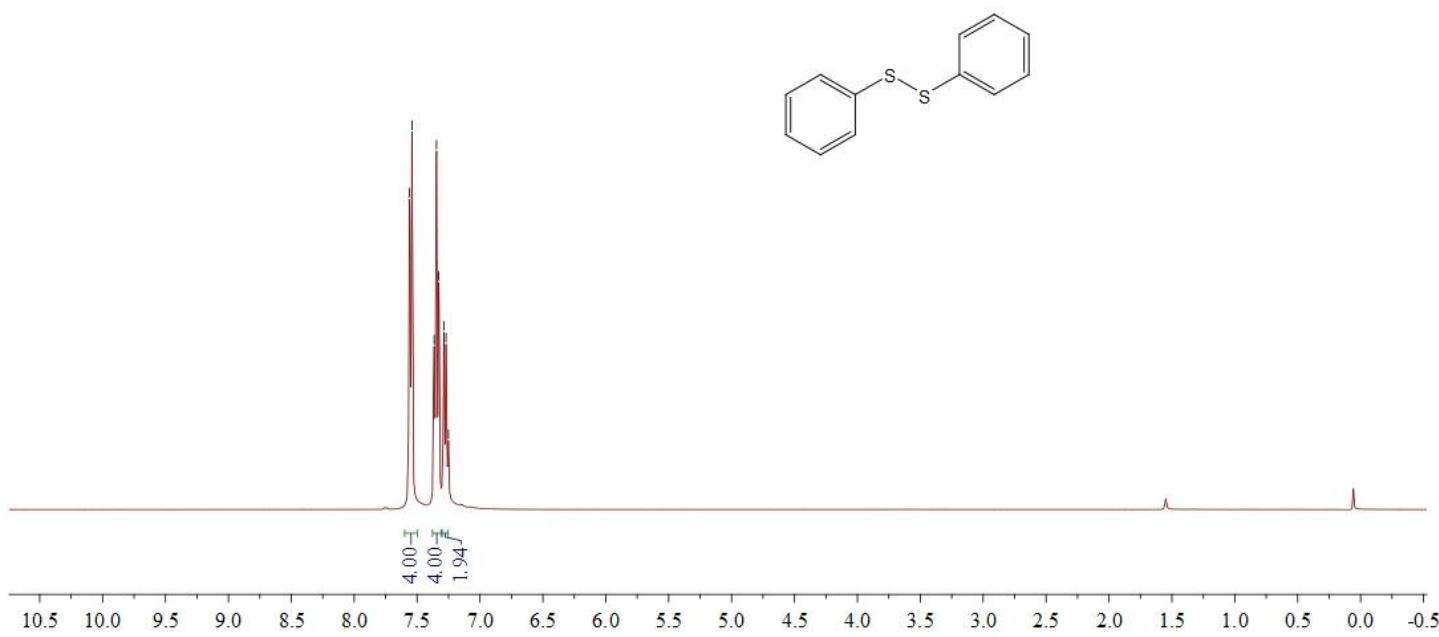

${ }^{13} \mathrm{C}$ spectra of 1,2-diphenyldisulfane
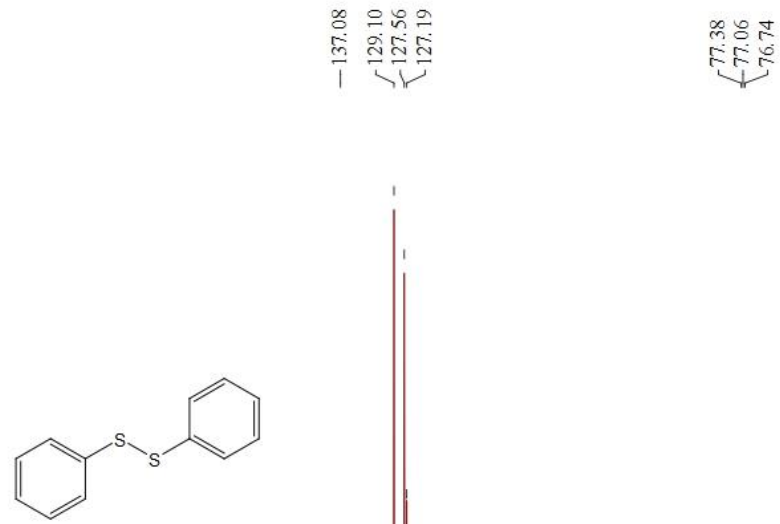

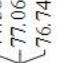

$\begin{array}{lllllllllllllllllllll}200 & 190 & 180 & 170 & 160 & 150 & 140 & 130 & 120 & 110 & 100 & 90 & 80 & 70 & 60 & 50 & 40 & 30 & 20 & 10 & 0\end{array}$ 